\title{
Pertumbuhan dan Hasil Tanaman Selada (Lactuca sativa L.) pada Tanah Ultisol dengan Pemberian Bokashi Pelepah Kelapa Sawit
}

\author{
Akhmad Rizali* \\ Agroekoteknologi, Fakultas \\ Pertanian Universitas \\ Lambung Mangkurat \\ Banjarbaru, Banjarbaru, \\ 70714. arizali25@yahoo.com \\ *Corresponding author
}

\author{
Nurlaila \\ Agroekoteknologi, Fakultas \\ Pertanian Universitas \\ Lambung Mangkurat \\ Banjarbaru, Banjarbaru, \\ 70714. \\ nurlaila@ulm.ac.id
}

\author{
Maya Septiani \\ Agroekoteknologi, Fakultas \\ Pertanian Universitas Lambung \\ Mangkurat Banjarbaru, \\ Banjarbaru, 70714. \\ mayaseptian600@gmail.com
}

\begin{abstract}
Abstrak - Selada (Lactuca sativa L.) merupakan tanaman yang memiliki nilai ekonomis yang baik. Permintaan selada terus meningkat dalam beberapa tahun terakhir. Data Base Gizi Nasional USDA (2018) menyebutkan bahwa selain sebagai bahan pelengkap nabati, dalam 100 gram selada mengandung 0,15 gram lemak, 1,36 gram protein, 2,87 gram karbohidrat, dan energi 15 kalori. Penelitian ini bertujuan untuk mengetahui pengaruh dosis bokashi terbaik terhadap pertumbuhan dan hasil tanaman selada. Penelitian ini dilakukan di Rumah Kaca Agroekoteknologi selama 3 bulan, mulai bulan Juni hingga Agustus. Penelitian ini menggunakan Rancangan Acak Lengkap (RAL) dari faktor tunggal dan diulang sebanyak 5 kali. Perlakuan penelitian adalah pemberian bokashi dengan dosis berbeda pada media tanah dengan 5 taraf perlakuan yang terdiri dari B0 (lapisan tanah atas tanpa bokashi), B1 (lapisan tanah dengan 10 ton / ha bokashi), B2 (lapisan tanah bawah dengan 20 ton bokashi. / ha), B3 (subsoil dengan 30 ton / ha bokashi), B4 (subsoil dengan 40 ton / ha bokashi). Sehingga terdapat 5 perlakuan dalam penelitian, masing-masing perlakuan diulang sebanyak 5 kali. Jadi, dalam penelitian ini terdapat 25 unit eksperimen.
\end{abstract}

Kata Kunci - Tanah, Selada, Bokashi, Ultisol.

\section{Pendahuluan}

Indonesia merupakan negara yang memiliki tingkat kebutuhan gizi yang tinggi terutama kebutuhan gizi dari produktifitas hortikultura. Kebutuhan yang harus terpenuhi salah satunya adalah mengkonsumsi sayuran. Selada adalah sayuran yang termasuk memiliki nilai gizi yang tinggi, karena meningkatnya kebutuhan konsumen, tanaman selada ini dapat dijadikan peluang usaha guna memenuhi permintaan dari konsumen (Haryanto et al., 2003).

Selain memiliki nilai ekonomi yang tinggi. Dalam beberapa tahun permintaan konsumen terhadap tanaman selada juga terus meningkat. Menurut USDA National Nutrient Data Base (2018), selain digunakan sebagai bahan tambahan makanan, selada memiliki kandungan energy sebanyak 2,87 gram karbohidrat, 15 kalori, 1,36 gram protein, dan 0,15 gram lemak yang terdapat pada 100 gram tanaman selada. Ciri fisik tanaman selada memiliki akar yang pendek yang menyebabkan harus memiliki media tanam yang subur dan gembur.

Kelapa sawit (Elaies guineensis Jacq) merupakan tanaman hortikultura yang mempunyai pendapatan ekonomi yang terus meningkat, tanaman hortikultura ini memiliki banyak manfaat dan sangat dibutuhkan setelah di produksi menjadi minyak diesel, biomas, kompos dan minyak sawit (CPO). Badan Pusat Statistik Riau (2010) mengatakan bahwa pelepah daun kelapa sawit sampai sekarang tidak digunakan dengan baik dan hanya di tumpuk di area perkebunan kelapa sawit saja.

Penyebaran tanah suboptimal atau tanah marginal mencapai $57,22 \%$ dari luas pulau yaitu sebanyak 30,15 juta hektar. Yang terdiri dari beberapa jenis tanah utama yaitu Oxisols, Inceptisols dan Ultisol. Tanah tersebut sebagian besar dimanfaatkan untuk tanaman perkebunan seperti tanaman lada, kopi, karet, kelapa sawit dan hutan tanaman industri.

Menurut BPS Bengkulu (2007), kelapa sawit pada saat sekali panen menghasilkan 200 sampai 400 produk samping perhektar lahan. Pelepah daun kelapa sawit disebut produk samping (by product) karena pada saat pemanenan atau sedang mengambil buahnya pelepah daun kelapa sawit ikut terlepas dari pohonnya. Karena hal tersebut, perlu adanya tindakan untuk pemanfaatan pelepah daun kelapa sawit dengan menjadikannya puouk organik. Pendapat Pahan (2008) unsur hara yang terkandung pada pelepah yaitu $0,90-1,20 \%$ kalium, $0,15-$ $0,18 \%$ phosphor, 2,4-2,8 nitrogen, 0,25-0,4\% magnesium, serta unsur hara lainnya. Data BPS (2004) menyebutkan bahwa di Kalimantan memiliki luas

\section{METODOLOGI}

Penelitian ini menggunakan metode Rancangan Acak Lengkap (RAL) faktor tunggal. Adapun faktor yang di pakai adalah dosis bokashi pelepah sawit. Perlakuan penelitian adalah pemberian bokashi dengan dosis yang berbeda pada 
media tanah subsoil. Terdiri dari 5 (lima) perlakuan dengan 5 (lima) ulangan. sehingga didapat sebanyak 25 satuan percobaan.

Adapun taraf perlakuan sebagai berikut:

$\mathrm{B}_{0}=$ topsoil (kontrol)

$\mathrm{B}_{1}=10$ ton/ha bokashi

$\mathrm{B}_{2}=20$ ton/ha bokashi

$\mathrm{B}_{3}=30$ ton/ha bokashi

$\mathrm{B}_{4}=40$ ton/ha bokashi

\section{A. Pelaksanaan Penelitian}

Pelaksanaan penelitian dimulai dari pengambilan bahan baku bokashi yaitu pelepah daun kelapa sawit, kemudian pembuatan bokashi. Pembuatan bokashi diawali dengan penyiapan bahan dan alat selama pengomposan, kemudian menghaluskan pelepah daun kelapa sawit dengan mesin pencacah, mencampurkan bahan utama pelepah daun kelapa sawit sebanyak 2,5 kilogram, pupuk kotoran ayam sebanyak 2,5 kilogram dan dedak sebanyak $2,5 \mathrm{~kg}$. kemudian melarutkan gula merah sebanyak 75 gram dan EM4 sebanyak $75 \mathrm{ml}$ dalam $1.000 \mathrm{ml}$ air. Kemudian mencampurkan semua bahan yang telah di olah dan di aduk. Proses pengomposan memerlukan waktu sebanyak 14 hari secara semi anaerob. Pengamatan dilakukan selama 14 hari pada waktu 3 hari sekali dengan mengamati temperatur, bau, warna, tekstur dan $\mathrm{pH}$ bokashi sampai bokashi menunjukkan ciri-ciri kematangan. Pembuatan bokashi dilakukan sekaligus dengan persemaian benih selada agar waktu penanaman dan inkubasi bokashi dengan media tanam sesuai. Penyemaian menggunakan tray dengan ukuran lebar sebesar 20 sentimeter dan panjang sebesar 20 sentimeter, lalu biji selada dihamburkan. Bahan yang digunakan yaitu ultisol dicampurkan dengan pupuk kotoran ayam dengan kedalaman $0,50 \mathrm{~cm}$ dan perbandingan $1: 1$, setelah itu ditutupi tanag secara merata. Penyemaian selada dilakukan dengan waktu 14 hari. Setelah bokashi menujukkan ciri-ciri matang, maka dilakukan analisis $\mathrm{pH}$ dengan menggunakan $\mathrm{pH}$ meter, analisis $\mathrm{C} / \mathrm{N}$ Rasio dan kandungan $\mathrm{N}, \mathrm{P}, \mathrm{K}$, dan kandungan air. Analisis ini dilakukan di Laboraturium Balitra Banjarbaru. Gambar Pelaksanaan Penelitian dapat kita lihat pada gambar 1 .

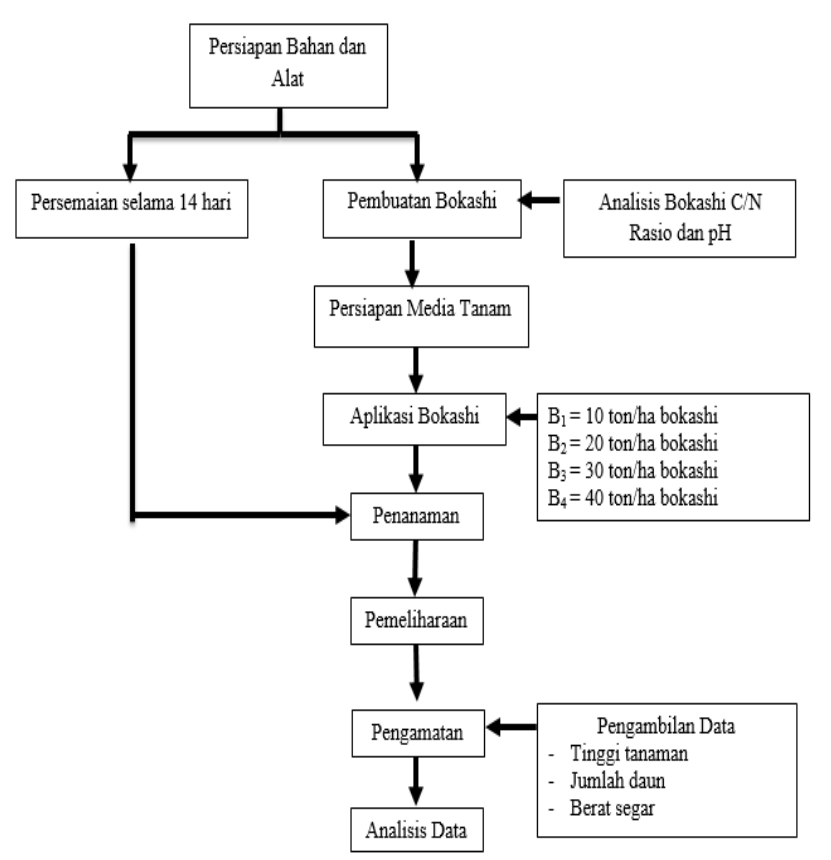

Gambar 1. Pelaksanaan Penelitian

\section{B. Analisis Data}

Penelitian ini mendapatkan data yang terdiri dari data sekunder (penunjang) dan data primer (utama). Data primer terdiri dari jumlah daun, tinggi tanaman dan berat segar. Data primer dikaji secara statistik dengan uji kehomogenan Levene Test. Jika data yang diuji tidak homogen dilakukan transformasi dan dilanjutkan dengan Analisis Ragam analysis of variance (ANOVA) terhadap variabel yang diamati. Jika data berpengaruh nyata terhadap variabelvariabel yang diamati dilanjutkan dengan uji Duncan Multiple Range Test (DMRT) taraf 5\%, Steel dan Torrie (1991). Data penunjang terdiri dari suhu selama pembuatan bokashi, $\mathrm{pH}$ media tanam pada masing-masing polybag, $\mathrm{C} / \mathrm{N}$ Rasio bokashi pelepah kelapa sawit, $\mathrm{pH}$ selama pembuatan bokashi dan kandungan air pada waktu pembuatan bokashi dan uji laboraturium pada bokashi untuk mengetahui adanya kandungan unsur NPK. Data penunjang yang diperoleh disajikan secara deskriptif. gambar Analisis Data dapat kita lihat pada gambar 2 .

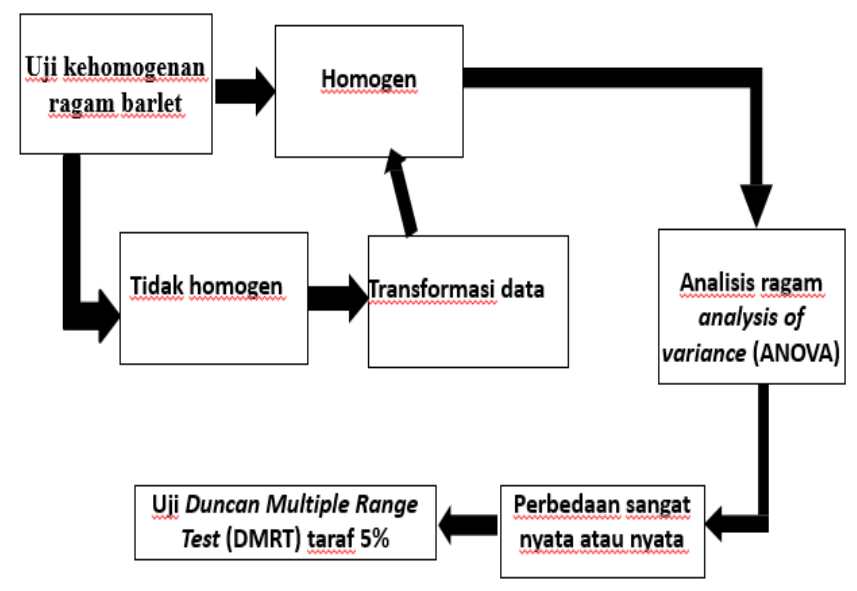

Gambar 2. Analisis Data 


\begin{tabular}{lllll}
\hline \multirow{2}{*}{ Perlakuan } & \multicolumn{4}{l}{ Jumlah daun (helai) } \\
\cline { 2 - 5 } & $10 \mathrm{HST}$ & $20 \mathrm{HST}$ & $30 \mathrm{HST}$ & $40 \mathrm{HST}$ \\
\hline $\mathrm{B}_{0}$ & 4.60 & 4.80 & 5.60 & 6.60 \\
$\mathrm{~B}_{1}$ & 4.40 & 5.20 & 5.60 & 7.20 \\
$\mathrm{~B}_{2}$ & 5.00 & 5.40 & 6.20 & 7.60 \\
$\mathrm{~B}_{3}$ & 4.60 & 5.20 & 5.80 & 8.00 \\
$\mathrm{~B}_{4}$ & 4.60 & 5.00 & 6.40 & 8.00 \\
\hline
\end{tabular}

\section{HASIL DAN PEMBAHASAN}

a. Hasil Penelitian

Tinggi tanaman

Hasil analisis sidik ragam menunjukkan dengan penambahan bokasi pelapah sawit disajikan pada Lampiran 5. Hasil uji analisis ragam berpengaruh nyata terhadap tinggi tanaman selada pada hari 20 HST dan 30 HST, berpengaruh sangat nyata terhadap tinggi tanaman selada pada umur 40 HST setelah dikaji lanjut dengan uji Duncan Multiple Range Test (DMRT). Pengaruh pemberian bokasi pelapah sawit pada parameter tinggi tanaman selada dapat dilihat pada Tabel 1.

Tabel 1. Analisis uji 1anjut Duncan Multiple Range Test (DMRT) terhadap rata-rata tinggi tanaman selada (Lactuca sativa L.) umur 10, 20, 30, dan 40 HST dengan pemberian bokashi pelepah kelapa sawit pada tanah ultisol.

\begin{tabular}{lllll}
\hline \multirow{2}{*}{ Perlakuan } & \multicolumn{5}{c}{ Tinggi Tanaman $(\mathrm{cm})$} \\
& $10 \mathrm{HST}$ & HST & $30 \mathrm{HST}$ & $40 \mathrm{HST}$ \\
\hline $\mathrm{B}_{0}$ & $6.90 \mathrm{a}$ & $8.80 \mathrm{a}$ & $10.10 \mathrm{a}$ & $12.56 \mathrm{a}$ \\
$\mathrm{B}_{1}$ & $5.40 \mathrm{a}$ & $8.64 \mathrm{a}$ & $12.44 \mathrm{ab}$ & $18.06 \mathrm{~b}$ \\
$\mathrm{~B}_{2}$ & $7.00 \mathrm{a}$ & $13.60 \mathrm{~b}$ & $17.20 \mathrm{bc}$ & $24.80 \mathrm{c}$ \\
$\mathrm{B}_{3}$ & $7.00 \mathrm{a}$ & $12.38 \mathrm{~b}$ & $16.40 \mathrm{bc}$ & $25.44 \mathrm{~cd}$ \\
$\mathrm{~B}_{4}$ & $6.86 \mathrm{a}$ & $12.80 \mathrm{~b}$ & $19.30 \mathrm{c}$ & $30.14 \mathrm{~d}$ \\
\hline
\end{tabular}

Keterangan: Nilai rata-rata yang diikuti dengan huruf yang sama pada kolom yang sama menunjukkan pengaruh yang sama berdasarkan uji DMRT (Duncan Multiple Range Test) taraf 5\%.

$$
\begin{aligned}
& \mathrm{B}_{0}=\text { topsoil (kontrol) } \\
& \mathrm{B}_{1}=10 \text { ton/ha bokashi } \\
& \mathrm{B}_{2}=20 \text { ton/ha bokashi } \\
& \mathrm{B}_{3}=30 \text { ton/ha bokashi } \\
& \mathrm{B}_{4}=40 \text { ton/ha bokashi }
\end{aligned}
$$

\section{Jumlah daun}

Hasil analisis sidik ragam menunjukkan bahwa penambahan bokashi pelapah sawit disajikan pada Lampiran 6. Hasil uji analisis ragam tidak berpengaruh

\begin{tabular}{|c|c|c|c|c|c|}
\hline \multicolumn{6}{|c|}{ Berat Segar } \\
\hline Perlakuan & $\mathrm{B}_{0}$ & $\mathrm{~B}_{1}$ & $\mathrm{~B}_{2}$ & $\mathrm{~B}_{3}$ & $\mathrm{~B}_{4}$ \\
\hline Rata-rata & $\begin{array}{l}1.96 \\
\mathrm{a}\end{array}$ & $\begin{array}{l}4.63 \\
\mathrm{~b}\end{array}$ & $\begin{array}{l}11.72 \\
b c\end{array}$ & $\begin{array}{l}10.56 \\
b\end{array}$ & $19.51 b c$ \\
\hline
\end{tabular}
nyata terhadap jumlah daun tanaman selada pada umur 10 , 20,30, dan pada umur 40 HST. Pengaruh pemberian bokasi pelapah sawit terhadap jumlah daun tanaman selada dapat dilihat pada Tabel 2 berikut ini.

Tabel 2. Analisis sidik ragam terhadap rata-rata jumlah daun (helai) tanaman selada (Lactuca sativa L.) dengan perlakuan pemberian bokashi pelepah kelapa sawit pada tanah ultisol.

Keterangan : $\quad \mathrm{B}_{0}=$ topsoil (kontrol)

$\mathrm{B}_{1}=10$ ton/ha bokashi

$\mathrm{B}_{2}=20$ ton/ha bokashi

$\mathrm{B}_{3}=30$ ton/ha bokashi

$\mathrm{B}_{4}=40$ ton/ha bokashi

Berat Segar

Berdasarkan hasil analisis yang disajikan pada Lampiran 7, hasil uji analisis ragam menunjukkan bahwa pemberian bokasi pelapah sawit berpengaruh nyata terhadap berat segar pada tanaman selada. Pengaruh pemberian bokasi pelapah sawit terhadap berat segar tanaman selada bisa dilihat pada Tabel 3 .

Tabel 3. Analisis uji lanjut Duncan Multiple Range Test (DMRT) terhadap berat segar tanaman selada (Lactuca sativa L.) umur 10, 20, 30, dan 40 HST dengan pemberian bokashi pelepah kelapa sawit pada tanah ultisol.

Keterangan: Angka yang diikuti dengan huruf dan baris yang sama menunjukkan pengaruh yang sama berdasarkan uji DMRT (Duncan Multiple Range Test) taraf 5\%.

$\mathrm{B}_{0}=$ topsoil (kontrol)

$\mathrm{B}_{1}=10$ ton/ha bokashi

$\mathrm{B}_{2}=20$ ton/ha bokashi

$\mathrm{B}_{3}=30$ ton/ha bokashi

$\mathrm{B}_{4}=40$ ton/ha bokashi

$\mathrm{pH}$ tanah

Hasil analisis sidik ragam menunjukkan bahwa pemberian bokasi pelapah sawit tidak berpengaruh terhadap $\mathrm{pH}$ tanah. $\mathrm{pH}$ tanah pada media tanam dengan perlakuan pemberian bokashi pelepah kelapa sawit bisa dilihat di tabel 4 berikut.

Tabel 4. Analisis sidik ragam terhadap $\mathrm{pH}$ tanah pada media tanam tanaman selada (Lactuca sativa L.) dengan perlakuan pemberian bokashi pelepah kelapa sawit pada tanah ultisol.

\begin{tabular}{clllll}
\hline pH Tanah & & & \\
\hline Perlakuan & $\mathrm{B}_{0}$ & $\mathrm{~B}_{1}$ & $\mathrm{~B}_{2}$ & $\mathrm{~B}_{3}$ & $\mathrm{~B}_{4}$ \\
\hline Rata-rata & 6.16 & 5.86 & 6.02 & 6.34 & 6.30 \\
\hline Keterangan : & \multicolumn{5}{c}{$\mathrm{B}_{0}=$ topsoil (kontrol) } \\
& $\mathrm{B}_{1}=10$ ton/ha bokashi \\
& $\mathrm{B}_{2}=20$ ton/ha bokashi \\
& $\mathrm{B}_{3}=30$ ton/ha bokashi \\
& $\mathrm{B}_{4}=40$ ton/ha bokashi
\end{tabular}

b. Pembahasan

Pelepah sawit merupakan sampah organik yang belum dimanfaaatkan oleh masyarakat, terutama untuk 
petani kelapa sawit dan perusahaan-perusahaan sawit. Pelepah sawit memiliki nilai guna sama seperti tandan kosong dan cangkang. Pendapat Sugiyono (1998) kandungan unsur hara makro yang terdapat pada pelepah sawit $\mathrm{Ca}=0,37-0,68 \%, \mathrm{Mg}=0,13-0,36$ dan $\mathrm{K}=2,75$ $3,74 \%$. Berdasarkan data analisis Laboraturium terhadap bokashi pelepah kelapa sawit menunjukkan bahwa kandungan N, P dan K nya masih rendah. Unsur hara makro yang terkandung pada bokashi dihasilkan pada pelepah kelapa sawit masih rendah dan belum memenuhi standar yang telah ditentukan oleh Standar Nasional Indonesia (SNI) 19-7030-2004. Namun menurut Widawati et al. (2010), pemberian bahan organik pada tanah memiliki manfaat yang besar antara membenahi susunan tekstur tanah yang menyebabkan pergerakan air tanah dan aerasi udara lancar, sehingga bias meningkatkan penyerapan air dalam tanah kemudian meningkatkan pertumbuhan serta produksi tanaman. Manfaat pemberian pupuk organik ditambahkan Suliasih et al. (2010), meningkatkan hara tersedia bagi tanaman meningkatkan populasi dan aktivitas mikroorganisme tanah yang cukup untuk pertumbuhan tinggi tanaman dan berat basah, namun masih belum cukup untuk jumlah daun.

\section{Tinggi Tanaman}

Pada Tabel 1 menyatakan bahwa hasil rerata tinggi tanaman selada (Lactuca sativa L.) dengan pemberian bokashi pelepah sawit berdasarkan DMRT (Duncan Multiple Range Test) menunjukkan bahwa pada umur 10 HST semua taraf perlakuan tidak berpengaruh nyata pada perlakuan kontrol (B0) sebesar 6,90 cm, perlakuan (B1) sebesar 5,40 cm, perlakuan (B2) sebesar 7,00 cm, perlakuan (B3) sebesar 7,00 cm, dan perlakuan (B4) sebesar $6,86 \mathrm{~cm}$. Pemberian dosis bokashi pelepah sawit yang tertinggi terhadap tinggi tanaman terdapat pada perlakuan (B2) dan (B3) memiliki angka yang sama sebesar 7,00 $\mathrm{cm}$. Pada umur 20 HST pada perlakuan kontrol (B0) sebesar $8,80 \mathrm{~cm}$ berpengaruh nyata terhadap perlakuan (B2) sebesar 13,60 cm, perlakuan (B3) sebesar $12,38 \mathrm{~cm}$, dan perlakuan (B4) sebesar 12,80 cm. Demikian juga pada perlakuan (B1) berpengaruh nyata dengan perlakuan (B2) sebesar 13,60 cm, perlakuan (B3) sebesar $12,38 \mathrm{~cm}$, dan perlakuan (B4) sebesar 12,80 cm. Pada umur 30 HST pada perlakuan kontrol (B0) dengan nilai $10,10 \mathrm{~cm}$ berpengaruh nyata terhadap perlakuan (B1) dengan nilai 12,44 cm, perlakuan (B2) dengan nilai 17,20 $\mathrm{cm}$, perlakuan (B3) dengan nilai $16,40 \mathrm{~cm}$, dan perlakuan (B4) dengan nilai 19,30 cm. Pada umur 40 HST pada perlakuan kontrol (B0) sebesar $12,56 \mathrm{~cm}$ berpengaruh nyata terhadap perlakuan (B1) dengan nilai $18,06 \mathrm{~cm}$, perlakuan (B2) dengan nilai $24,80 \mathrm{~cm}$, perlakuan (B3) dengan nilai $25,44 \mathrm{~cm}$, dan perlakuan (B4) dengan nilai $30,14 \mathrm{~cm}$.

Tinggi tanaman pada perlakuan dosis pemberian bokashi pelepah kelapa sawit pada tanaman selada bepengaruh nyata diduga karena pemberian pupuk alami bias memulihkan susunan tekstur tanah yang dapat menambah daya serap air dan unsur hara meskipun sedikit untuk pertumbuhan tinggi tanaman sesuai dengan pendapat Widawati et al. (2010). Ditambahkan Annabi et al. (2006) menyatakan kalau selain penambahan bahan organik dapat meningkatkan kadar $\mathrm{C}$ organik untuk pertumbuhan tinggi tanaman dan penambahan bahan organik pada media tanam dapat meningkatkan kadar $\mathrm{C}$ organik. Meningkatnya $\mathrm{C}$ organik menyebabkan kandungan unsur hara pada bahan organik berupaya untuk menaikkan unsur hara dalam tanah dan membaiknya kondisi tanah bagi aktifitas mikroorganisme.

\section{Jumlah Daun}

Hasil analisis sidik ragam membuktikan pada Tabel 2 jumlah daun pada semua perlakuan pemberian bokashi pelepah kelapa sawit pada tanaman selada (Lactuca sativa L.) tidak berbeda nyata pada semua taraf perlakuan dosis terhadap jumlah daun pada umur 10, 20, 30, dan 40 HST. Pada umur 10 HST perlakuan kontrol (B0) sebesar 4,60 helai tidak berbeda nyata terhadap perlakuan (B1) sebesar 4,40 helai, perlakuan (B2) sebesar 5,00 helai, perlakuan (B3) sebesar 4,60 helai, dan perlakuan (B4) sebesar 4,60 helai. Pada umur 20 HST perlakuan kontrol (B0) sebesar 4,80 helai tidak berbeda nyata terhadap perlakuan (B1) sebesar 5,20 helai, perlakuan (B2) sebesar 5,40 helai, perlakuan (B3) sebesar 5,20 helai, dan perlakuan (B4) sebesar 5,00 helai. Pada umur 30 HST perlakuan kontrol (B0) sebesar 5,60 helai tidak berbeda nyata terhadap perlakuan (B1) sebesar 5,60 helai, perlakuan (B2) sebesar 6,20 helai, perlakuan (B3) sebesar 5,80 helai, dan perlakuan (B4) sebesar 6,40 helai. Pada umur $40 \mathrm{HST}$ perlakuan kontrol (B0) sebesar 6,60 helai tidak berbeda nyata terhadap perlakuan (B1) sebesar 7,20 helai, perlakuan (B2) sebesar 7,60 helai, perlakuan (B3) sebesar 8,00 helai, dan perlakuan (B4) sebesar 8,00 helai.

Perlakuan pemberian bokashi pelepah kelapa sawit pada dosis 40 ton/ha (B4) dan 30 ton/ha (B3) menghasilkan jumlah daun paling banyak pada umur 40 HST sebesar 8,00 helai. Namun, perlakuan (B3) dan (B4) menghasilkan angka yang sama terhadap jumlah daun yaitu sebesar 8,00 helai.

Perlakuan pemberian dosis pelepah kelapa sawit tidak berbeda nyata pada jumlah daun pada umur 10, 20, 30, dan 40 HST diduga karena unsur hara Nitrogen pada bokashi yang berfungsi untuk pertumbuhan jumlah daun masih rendah, berdasarkan hasil analisis Laboraturium terhadap kandungan unsur hara Nitrogen tersebut masih belum sesuai dengan Standar Nasional Indonesia (SNI), sehingga tidak cukup untuk pertumbuhan jumlah daun. Suliasih et al. (2010) menyatakan bahwa unsur hara yang terkandung yang belum maksimal akan mengurangi pertumbuhan jumlah daun karena kadar unsur hara nya belum memenuhi. Menurut Lakitan (1996), Nitrogen (N) adalah unsur hara yang paling penting terhadap perkembangan dan pertumbuhan jumlah daun. Mempunyai daun yang banyak diduga memiliki kadar unsur $\mathrm{N}$ yang optimal. Humphries \& Wheelr, (1963) menambahkan bahwa jumlah daun memiliki pengaruh terhadap faktor genetik dan faktor lingkungan, terutama pada tanaman yaitu letak daun dikendalikan oleh genotip, juga mempengaruhi tumbuhnya daun, sedangkan pertumbuhan dan perkembangan daun antara lain temperatur, udara, 
ketersediaan air dan unsur hara dipengaruhi oleh faktor lingkungan.

\section{Berat Segar}

Tabel 4 membuktikan kalau berat segar tanaman selada dengan perlakuan pemberian bokashi pelepah kelapa sawit dengan pemberian berdasarkan Duncan Multiple Range Test (DMRT) memperlihatkan perlakuan kontrol (B0) sebesar 1,96 g berpengaruh nyata terhadap perlakuan (B1) sebesar 4,63 g, perlakuan (B2) dengan nilai $11,72 \mathrm{~g}$, perlakuan (B3) senilai $10,56 \mathrm{~g}$, dan perlakuan (B4) sebesar 19,51 g. Perlakuan (B1) sebesar 4,63 g berbeda nyata dengan perlakuan (B2) sebesar 11,72 g dan perlakuan (B3) sebesar 10,56 g. Perlakuan (B2) sebesar 11,72 g berbeda nyata terhadap perlakuan (B3) sebesar 10,56 g dan perlakuan (B4) sebesar 19,51 g. Perlakuan (B3) sebesar 10,56 g berbeda nyata dengan perlakuan (B4) sebesar 19,51 g. Hal ini diduga karena berat segar merupakan akumulasi dari penggunaan unsur hara, karena kandungan unsur hara yang rendah bokashi menyebabkan kadar unsur hara tidak cukup untuk meningkatkan berat segar tanaman selada. Sebagaimana dengan berat segar adalah jumlah pengumpulan fotosintat dalam kandungan air pada daun dan bentuk biomassa tanaman. Pendapat Lahadassy (2007), berat segar tanaman yang optimal harus banyak memerlukan energi ataupun unsur hara agar penambahan jumlah ataupun bentuk sel dapat mencapai optimal serta menyebabkan adanya penambahan kandungan air tanaman yang optimal. Ditambahkan kembali oleh Loveless (1987), kandungan air juga menyebabkan penambahan terhadap berat segar tanaman.

\section{$\mathrm{pH}$ tanah}

Berdasarkan hasil analisis sidik ragam terhadap $\mathrm{pH}$ pada Tabel 3 menunjukkan bahwa semua perlakuan pemberian bokashi pelepah kelapa sawit tidak berbeda nyata dengan perlakuan control (B0) sebesar 6,16, perlakuan (B1) sebesar 5,86, perlakuan (B2) sebesar 6,02, perlakuan (B3) sebesar 6,34, dan perlakuan (B4) sebesar 6,30. Rata-rata $\mathrm{pH}$ tertinggi terdapat pada perlakuan (B3) yaitu sebesar 6,34. Dengan pemberian perlakuan bokashi pelepah kelapa sawit, $\mathrm{pH}$ media tanam mengalami penurunan.Terutama pada pemberian perlakuan dosis 10 ton/ha (B1) sebesar 5,86. Namun dengan pemberian perlakuan dosis bokashi yang semakin tinggi meningkatkan $\mathrm{pH}$ media tanam pada perlakuan dosis (B3) yaitu 6,34. pH yang diamati pada media tanam yang sudah dicampur dengan bokashi sesuai dosis perlakuan, pengukuran $\mathrm{pH}$ dilakukan satu kali pada awal penanaman. Perlakuan pemberian bokashi pelepah kelapa sawit pada media tanam tidak berbeda nyata terhadap $\mathrm{pH}$ awal pada tanah subsoil sebesar 4,81 dan pada tanah topsoil sebesar 4,69. Hal ini diduga karena $\mathrm{pH}$ tanah masih rendah dan belum memenuhi terhadap $\mathrm{pH}$ media tanam, hal ini sesuai dengan pendapat Hardjowigeno, 2003) menyatakan bahwa topsoil (tanah lapisan atas) adalah tanah yang memiliki kandungan bahan organik atau humus. Humus bias saja berasal dari sisa-sisa makhluk hidup yang terurai dalam topsoil. Keberadaan subsoil apabila semakin dalam lapisannya maka akan semakin berkurang kandungan bahan organik dan unsur haranya.

\section{KESIMPULAN}

Pemberian bokashi pelepah sawit berbeda sangat nyata pada tinggi tanaman pada umur ke 40 HST dengan nilai ratarata $30,14 \mathrm{~cm}$ dan berpengaruh nyata terhadap berat segar nilai $19,51 \mathrm{~g}$ pada perlakuan pemberian bokashi dengan dosis 40 ton/ha, namun tidak berpengaruh nyata terhadap jumlah daun pada umur 10, 20, 30, dan 40 HST. Dosis terbaik pemberian bokashi pelepah sawit terdapat pada perlakuan pemberian bokashi dengan dosis 40 ton/ha $\left(B_{4}\right)$ pada jumlah daun, berat segar dan tinggi tanaman.

\section{DAFTAR PUSTAKA}

Annabi, M., S, Houot, C, Francou, M, Poltrenaud and Y. Le Bissonair. (2006). Soil Aggregate Stability Improvement with Urban Composts of different naturities. SSSAJ Vol. 71 No. 2, p. 413-423.

Badan Pusat Statistik Provinsi Bengkulu. (2007). Bengkulu dalam Angka. Biro Pusat Statistik.

Badan Pusat Statistik Riau.( 2010). Riau Dalam Angka 2010. http://Riau.bps.go.id/Riau dalam Angka2010/perkebunan.html. Diakses pada tanggal 0811-2020.

BPS. (2004). Statistik Indonesia. Badan Pusat Statistik, Jakarta.

Hardjowigeno S. (2003). Ilmu Tanah. Jakarta: Akademika Pressindo.

Haryanto E, Suhartini T, Rahayu E. (2003). Sawi dan Selada. Penebar Swadaya. Jakarta.

Humphries, E. C., dan C. R. Wheeler. (1963). Annu Rev. Plant Physiol. 14:385-410.

Lakitan, B. (1996). Fisiologi Pertumbuhan dan Perkembangan Tanaman. PT $>$ Raja Grafindo Persada. Jakarta.

Lahadassy.J. (2007). Pengaruh Dosis Pupuk Organik Padat Daun Gamal terhadap Tanaman Sawi. Jurnal Agrisistem, Volume.3, No.2, Desember 2007.

Loveless, A. R. (1987). Prinsip- Prinsip Biologi Bunga Tumbuhan untuk Daerah Trofik, Gramedia. Jakarta.

Pahan, I. (2008). Panduan Lengkap Kelapa Sawit Manajemen Agribisnis dari Hulu Hingga Hilir. Penebar Swadaya. Jakarta.

Suliasih, S.Widawati dan A. Muharam, (2010). Aplikasi Pupuk Organik dan Bakteri Pelarut Fosfat untuk Meningkatkan Pertumbuhan Tanaman Tomat Dan Aktivitas Mikroba Tanah. J. Hort.20(3):241-246.

Steel, R.G.D. dan J.H. Torrie.(1991). Prinsip dan Prosedur Statistika. Gramedia Pustaka Utama. Jakarta.

USDA National Nutrient Database for Standart Reference (2018), Lettuce Green Leaf, Basic Report, The National Agricultural Library.

Widawati, S., Suliasih, dan A. Muharam. (2010). Pengaruh Kompos yang Diperkaya Bakteri Penambat Nitrogen dan Pelarut Fosfat terhadap 